\title{
Exposure to Fipronil Insecticide in the Sixth Total Diet Study - China, 2016-2019
}

\author{
Zhibin Liu ${ }^{1,2}$; Dawei Chen ${ }^{1, *} ;$ Bing Lyu ${ }^{1}$; Jingguang Lii ${ }^{1}$; Yunfeng Zhao ${ }^{1}$; Yongning $\mathrm{Wu}^{1}$
}

\section{Summary \\ What is already known about this topic?}

Fipronil is classified as a "possible human carcinogen" by the United States Environmental Protection Agency. Long-term exposure to fipronil may cause damage to liver, thyroid, and kidney. However, fipronil and its metabolites are ubiquitous in the environment and food.

\section{What is added by this report?}

The dietary intake of fipronil in China was within acceptable levels with low health risk. Eggs were the main dietary intake contributor of fipronil for Chinese adult populations $(55.3 \%)$, followed by vegetables $(30.7 \%)$, meats $(5.90 \%)$, cereals $(5.30 \%)$, and other food categories contributed less than $2 \%$.

What are the implications for public health practice?

The study results will help health managers understand the health risk of fipronil, and help to better formulate monitoring plans in foods. It is still necessary to strengthen the monitoring of fipronil in foods, especially animal-derived foods.

Fipronil was widely used as an insecticide to kill crop pests. However, the use of fipronil has been restricted in China since 2009 due to its high toxicity to bees and a variety of aquatic organisms (1-3). During 2016-2019, the Sixth China Total Diet Study (TDS) was conducted to study the contamination status and health risk of total fipronils (FIPs) among 24 provincial-level administrative divisions (PLADs) in China. Based on residual data in dietary samples and national consumption data, the average estimated daily intake (EDI) of total FIPs in Chinese adult populations was assessed and compared with acceptable daily intake (ADI) of fipronil as a health-based guide value. In this study, total FIPs were detected in varying degrees in the 12 dietary categories with a mean of $1.96 \mu \mathrm{g} / \mathrm{kg}$. The average EDI of total FIPs in Chinese adult populations was $15.6 \mathrm{ng} / \mathrm{kg}$ body weight per day, accounting for $7.80 \%$ of the ADI $(200 \mathrm{ng} / \mathrm{kg}$ body weight per day). The Sixth China TDS showed that the dietary intake of total FIPs in China was within acceptable level with low health risks. Monitoring of fipronil in food and taking corresponding measures can effectively reduce the health risk of low-level fipronil exposure.

In China, GB 2763-2021 stipulated that fipronil residue should be calculated as the sum of fipronil, fipronil desulfinyl, fipronil sulfone, and fipronil sulfide. Currently, fipronil is only used as an insecticide on a few crop seed coatings, household hygiene products, etc. However, improper or excessive use of fipronil still occurs, leading to its residue in the environment and food.

The details of the Sixth China TDS (2016-2019) are referenced from the Foreword of this issue (4). An ultra-sensitive analytical method to cover a majority of dietary sample matrices was used based on our previous study (5). The instrument parameters were described in Supplementary Table S1 (available in https:// weekly.chinacdc.cn/). In this study, the limits of detection (LOD) of fipronil and its metabolites in 12 dietary samples were all $0.001 \mu \mathrm{g} / \mathrm{kg}$. Data and statistical analyses for residue levels and dietary exposure to total FIPs were performed using the GraphPad Prism (version 8.01, GraphPad Software, San Diego, CA) and SPSS (version 25.0, SPSS Inc, Chicago, IL, USA).

Residue data and detection frequencies for fipronil and its metabolites from the Sixth China TDS were shown in Table 1 and Supplementary Figure S1 (available in https://weekly.chinacdc.cn/). Among 288 dietary samples, the residue levels of total FIPs ranged from $<$ LOD to $383 \mu \mathrm{g} / \mathrm{kg}$ with a mean of $1.96 \mu \mathrm{g} / \mathrm{kg}$. The most frequently detected FIPs was fipronil sulfone with a detection frequency of $75.7 \%$, followed by fipronil $(60.1 \%)$, fipronil desulfinyl $(47.2 \%)$, and fipronil sulfide $(24.0 \%)$. According to the sample categories, egg samples from animal-derived foods showed the highest concentration of total FIPs with a 
TABLE 1. The levels of FIPs $(\mu \mathrm{g} / \mathrm{kg})$ and the detected frequency in the Sixth China TDS.

\begin{tabular}{|c|c|c|c|c|c|}
\hline Food category* & Fipronil & Fipronil desulfinyl & Fipronil sulfone & Fipronil sulfide & Total FIPs \\
\hline \multicolumn{6}{|l|}{ Total samples $(\mathrm{N}=288)$} \\
\hline $\mathrm{DF}(\%)$ & $60.1 \%$ & $47.2 \%$ & $75.7 \%$ & $24.0 \%$ & $76.0 \%$ \\
\hline Mean (Median, Range) & $\begin{array}{c}0.086 \\
(0.005, \mathrm{ND}-11.000)\end{array}$ & $\begin{array}{c}0.026 \\
(\mathrm{ND}, \mathrm{ND}-1.540)\end{array}$ & $\begin{array}{c}1.810 \\
(0.006, N D-372.000)\end{array}$ & $\begin{array}{c}0.033 \\
(\mathrm{ND}, \mathrm{ND}-5.720)\end{array}$ & $\begin{array}{c}1.960 \\
(0.022, \mathrm{ND}-383.000)\end{array}$ \\
\hline \multicolumn{6}{|l|}{ Cereals $(\mathrm{N}=24)$} \\
\hline DF $(\%)$ & $79.2 \%$ & $25.0 \%$ & $79.2 \%$ & $8.3 \%$ & $87.5 \%$ \\
\hline Mean (Median, Range) & $\begin{array}{c}0.025 \\
(0.007, \mathrm{ND}-0.156)\end{array}$ & $\begin{array}{c}0.003 \\
(\mathrm{ND}, \mathrm{ND}-0.019)\end{array}$ & $\begin{array}{c}0.041 \\
(0.005, \mathrm{ND}-0.653)\end{array}$ & $\begin{array}{c}0.002 \\
(\mathrm{ND}, \mathrm{ND}-0.025)\end{array}$ & $\begin{array}{c}0.070 \\
(0.025, \mathrm{ND}-0.771)\end{array}$ \\
\hline \multicolumn{6}{|l|}{ Legumes $(\mathrm{N}=24)$} \\
\hline DF $(\%)$ & $87.5 \%$ & $45.8 \%$ & $79.2 \%$ & $16.7 \%$ & $87.5 \%$ \\
\hline Mean (Median, Range) & $\begin{array}{c}0.017 \\
(0.016, \mathrm{ND}-0.045)\end{array}$ & $\begin{array}{c}0.003 \\
(\mathrm{ND}, \mathrm{ND}-0.014)\end{array}$ & $\begin{array}{c}0.007 \\
(0.004, \mathrm{ND}-0.040)\end{array}$ & $\begin{array}{c}0.002 \\
(\mathrm{ND}, \mathrm{ND}-0.016)\end{array}$ & $\begin{array}{c}0.028 \\
(0.021, \mathrm{ND}-0.085)\end{array}$ \\
\hline \multicolumn{6}{|l|}{ Potatoes $(\mathrm{N}=24)$} \\
\hline DF $(\%)$ & $79.2 \%$ & $37.5 \%$ & $100.0 \%$ & $20.8 \%$ & $100.0 \%$ \\
\hline Mean (Median, Range) & $\begin{array}{c}0.025 \\
(0.012, N D-0.210)\end{array}$ & $\begin{array}{c}0.003 \\
(\mathrm{ND}, \mathrm{ND}-0.016)\end{array}$ & $\begin{array}{c}0.017 \\
(0.005,0.002-0.147)\end{array}$ & $\begin{array}{c}0.003 \\
(\mathrm{ND}, \mathrm{ND}-0.023)\end{array}$ & $\begin{array}{c}0.048 \\
(0.019,0.004-0.245)\end{array}$ \\
\hline \multicolumn{6}{|l|}{ Meats $(\mathrm{N}=24)$} \\
\hline DF $(\%)$ & $91.7 \%$ & $83.3 \%$ & $100.0 \%$ & $37.5 \%$ & $100.0 \%$ \\
\hline Mean (Median, Range) & $\begin{array}{c}0.021 \\
(0.014, \mathrm{ND}-0.065)\end{array}$ & $\begin{array}{c}0.017 \\
(0.008, N D-0.140)\end{array}$ & $\begin{array}{c}0.518 \\
(0.077,0.011-9.69)\end{array}$ & $\begin{array}{c}0.006 \\
(\mathrm{ND}, \mathrm{ND}-0.108)\end{array}$ & $\begin{array}{c}0.561 \\
(0.111,0.017-9.73)\end{array}$ \\
\hline \multicolumn{6}{|l|}{ Eggs $(\mathrm{N}=24)$} \\
\hline DF $(\%)$ & $83.3 \%$ & $79.2 \%$ & $100.0 \%$ & $20.8 \%$ & $100.0 \%$ \\
\hline Mean (Median, Range) & $\begin{array}{c}0.566 \\
(0.013, \mathrm{ND}-11.000)\end{array}$ & $\begin{array}{c}0.013 \\
(0.003, N D-0.183)\end{array}$ & $\begin{array}{c}20.800 \\
(0.150,0.041-372.000)\end{array}$ & $\begin{array}{c}0.003 \\
(\mathrm{ND}, \mathrm{ND}-0.019)\end{array}$ & $\begin{array}{c}21.400 \\
(0.190,0.041-383.000)\end{array}$ \\
\hline \multicolumn{6}{|l|}{ Aquatic products $(\mathrm{N}=24)$} \\
\hline DF $(\%)$ & $95.8 \%$ & $95.8 \%$ & $100.0 \%$ & $83.3 \%$ & $100.0 \%$ \\
\hline Mean (Median, Range) & $\begin{array}{c}0.055 \\
(0.021, N D-0.418)\end{array}$ & $\begin{array}{c}0.138 \\
(0.044, N D-1.540)\end{array}$ & $\begin{array}{c}0.097 \\
(0.053,0.005-0.598)\end{array}$ & $\begin{array}{c}0.104 \\
(0.014, \mathrm{ND}-1.670)\end{array}$ & $\begin{array}{c}0.394 \\
(0.153,0.010-4.230)\end{array}$ \\
\hline \multicolumn{6}{|l|}{ Dairy products $(\mathrm{N}=24)$} \\
\hline $\begin{array}{l}\text { DF }(\%) \\
\text { Mean (Median, Range) }\end{array}$ & $\begin{array}{c}20.8 \% \\
0.006 \\
(N D, N D-0.114)\end{array}$ & $\begin{array}{c}70.8 \% \\
0.038 \\
(0.005, N D-0.763)\end{array}$ & $\begin{array}{c}100.0 \% \\
0.108 \\
(0.023,0.004-1.830)\end{array}$ & $\begin{array}{c}4.2 \% \\
0.003 \\
(\mathrm{ND}, \mathrm{ND}-0.060)\end{array}$ & $\begin{array}{c}100.0 \% \\
0.153 \\
(0.029,0.006-2.770)\end{array}$ \\
\hline \multicolumn{6}{|l|}{ Vegetables $(\mathrm{N}=24)$} \\
\hline $\mathrm{DF}(\%)$ & $95.8 \%$ & $83.3 \%$ & $100.0 \%$ & $54.2 \%$ & $100.0 \%$ \\
\hline Mean (Median, Range) & $\begin{array}{c}0.306 \\
(0.043, \mathrm{ND}-3.060)\end{array}$ & $\begin{array}{c}0.096 \\
(0.014, \text { ND-1.190) }\end{array}$ & $\begin{array}{c}0.157 \\
(0.057,0.002-1.350)\end{array}$ & $\begin{array}{c}0.269 \\
(0.002, \mathrm{ND}-5.720)\end{array}$ & $\begin{array}{c}0.827 \\
(0.138,0.006-11.300)\end{array}$ \\
\hline \multicolumn{6}{|l|}{ Fruits $(\mathrm{N}=24)$} \\
\hline DF $(\%)$ & $66.7 \%$ & $41.7 \%$ & $50.0 \%$ & $20.8 \%$ & $66.7 \%$ \\
\hline Mean (Median, Range) & $\begin{array}{c}0.009 \\
(0.005, \mathrm{ND}-0.058)\end{array}$ & $\begin{array}{c}0.002 \\
(\mathrm{ND}, \mathrm{ND}-0.006)\end{array}$ & $\begin{array}{c}0.002 \\
(0.001, N D-0.007)\end{array}$ & $\begin{array}{c}0.001 \\
(\mathrm{ND}, \mathrm{ND}-0.007)\end{array}$ & $\begin{array}{c}0.013 \\
(0.008, N D-0.068)\end{array}$ \\
\hline \multicolumn{6}{|l|}{ Sugars $(N=24)$} \\
\hline DF $(\%)$ & $0.0 \%$ & $0.0 \%$ & $58.3 \%$ & $4.2 \%$ & $58.3 \%$ \\
\hline Mean (Median, Range) & $\begin{array}{c}\mathrm{ND} \\
(\mathrm{ND}, \mathrm{ND})\end{array}$ & $\begin{array}{c}\mathrm{ND} \\
(\mathrm{ND}, \mathrm{ND})\end{array}$ & $\begin{array}{c}0.002 \\
(0.001, N D-0.009)\end{array}$ & $\begin{array}{c}\mathrm{ND} \\
(\mathrm{ND}, \mathrm{ND}-0.001)\end{array}$ & $\begin{array}{c}0.003 \\
(0.003, N D-0.011)\end{array}$ \\
\hline \multicolumn{6}{|c|}{ Beverages and water $(\mathrm{N}=24)$} \\
\hline $\mathrm{DF}(\%)$ & $16.7 \%$ & $4.2 \%$ & $25.0 \%$ & $16.7 \%$ & $25.0 \%$ \\
\hline Mean (Median, Range) & $\begin{array}{c}0.001 \\
(\mathrm{ND}, \mathrm{ND}-0.008)\end{array}$ & $\begin{array}{c}0.001 \\
(\mathrm{ND}, \mathrm{ND}-0.002)\end{array}$ & $\begin{array}{c}0.001 \\
(\mathrm{ND}, \mathrm{ND}-0.005)\end{array}$ & $\begin{array}{c}0.001 \\
(\mathrm{ND}, \mathrm{ND}-0.004)\end{array}$ & $\begin{array}{c}0.004 \\
(\mathrm{ND}, \mathrm{ND}-0.016)\end{array}$ \\
\hline \multicolumn{6}{|l|}{ Alcohols $(\mathrm{N}=24)$} \\
\hline DF $(\%)$ & $4.2 \%$ & $0.0 \%$ & $16.7 \%$ & $0.0 \%$ & $20.8 \%$ \\
\hline Mean (Median, Range) & $\begin{array}{c}0.001 \\
(\mathrm{ND}, \mathrm{ND}-0.003) \\
\end{array}$ & $\begin{array}{c}N D \\
(N D, N D) \\
\end{array}$ & $\begin{array}{c}0.001 \\
(\mathrm{ND}, \mathrm{ND}-0.004) \\
\end{array}$ & $\begin{array}{c}N D \\
(N D, N D) \\
\end{array}$ & $\begin{array}{c}0.002 \\
(\mathrm{ND}, \mathrm{ND}-0.005) \\
\end{array}$ \\
\hline
\end{tabular}

Abbreviations: TDS=total diet study; $\mathrm{DF}=$ detection frequency; $\mathrm{FIPs}=$ fipronils; $\mathrm{N}=$ =number of samples; $\mathrm{SD}=$ standard deviation; $\mathrm{ND}=\mathrm{non}$ detected value.

* The 12 food categories are clustered by their respective foods. 
mean of $21.4 \mu \mathrm{g} / \mathrm{kg}$, while vegetable samples from plant-derived food showed the second highest concentration with a mean of $0.827 \mu \mathrm{g} / \mathrm{kg}$. Using adult men as a representative population, the dietary

TABLE 2. Regional distribution of EDI of total FIPs in the Sixth China TDS.

\begin{tabular}{|c|c|c|c|c|c|c|c|c|c|c|c|c|c|c|c|c|c|c|c|c|c|c|c|}
\hline Item & HL & HE BJ & JL & $s x$ & SN & HA & $N X$ & NM & QH & GS & SH & FJ & $J X$ & JS & ZJ & SD & HB & sc & GX & $\mathrm{HN}$ & GD & GZ & AVG \\
\hline $\begin{array}{c}\text { EDI } \\
\text { (ng/kg }\end{array}$ & & & & & & & & & & & & & & & & & & & & & & & \\
\hline $\begin{array}{c}\text { body } \\
\text { weight } \\
\text { per day) }\end{array}$ & 1.3330 .20 & 6.0024 .20 & 1.23 & 2.47 & 2.28 & 1.00 & 1.07 & 26.40 & 0.391 & 136.00 & 6.67 & 6.85 & 8.11 & 1.66 & 8.25 & 2.98 & 11.00 & 0.65 & 65.40 & 8.46 & 20.30 & 1.07 & 15.60 \\
\hline ADI (\%) & 0.6715 .10 & 3.0012 .10 & 0.62 & 1.23 & 1.14 & 0.50 & 0.54 & 13.20 & 0.19 & 68.00 & 3.34 & 3.42 & 4.05 & 0.83 & 4.13 & 1.49 & 5.49 & 0.33 & 32.70 & 4.23 & 10.20 & 0.54 & 7.80 \\
\hline
\end{tabular}

Abbreviations: $\mathrm{EDI}=$ estimated dietary intake; $\mathrm{ADI}=$ acceptable daily intake; TDS=total diet study; FIPs=fipronils; AVG=average; $\mathrm{HL}=$ Heilongjiang; LN=Liaoning; HE=Hebei; BJ=Beijing; JL=Jilin; SX=Shanxi; SN=Shaanxi; HA=Henan; NX=Ningxia; NM=Inner Mongolia; $\mathrm{QH}=$ Qinghai; $\mathrm{GS}=$ Gansu; $\mathrm{SH}=$ Shanghai; $F J=F u j i a n ; J X=J i a n g x i ; J S=J i a n g s u ; Z J=Z h e j i a n g ; S D=S h a n d o n g ; H B=H u b e i ; S C=S i c h u a n ;$ $\mathrm{GX}=$ Guangxi; $\mathrm{HN}=$ Hunan; $\mathrm{GD}=$ Guangdong; $\mathrm{GZ}=$ Guizhou.

A

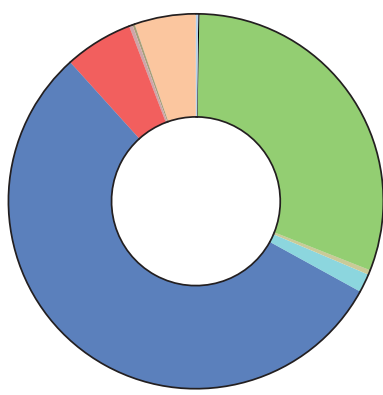

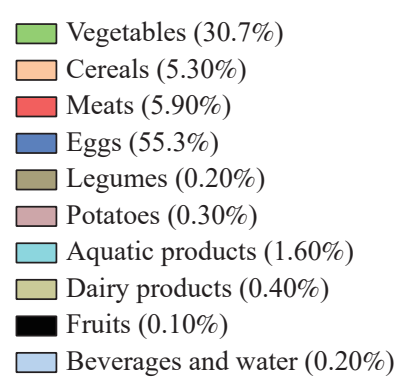

B
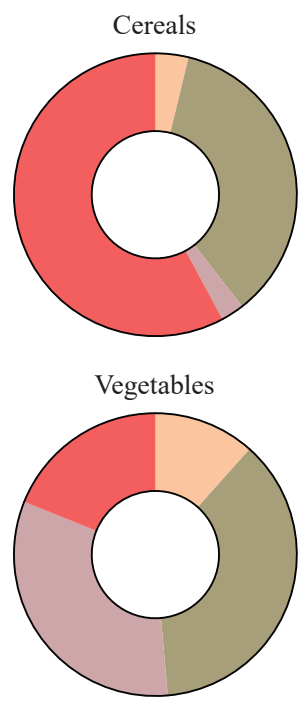

Aquatic products

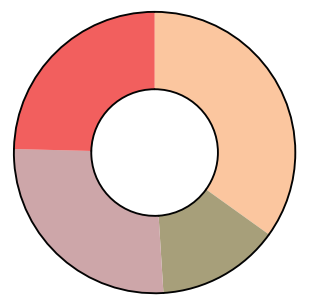

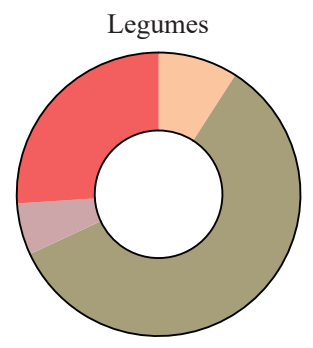

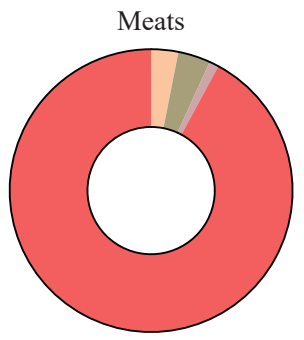

Dairy products

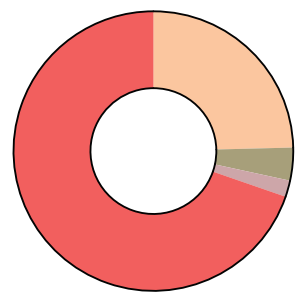

Potatoes
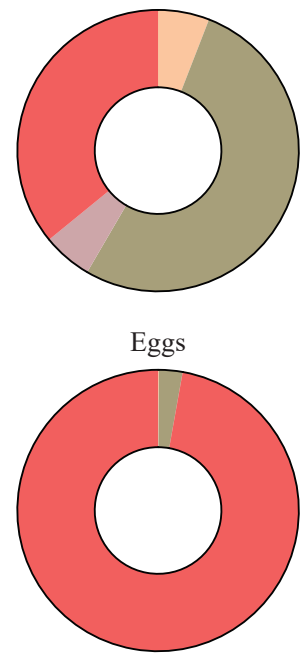

Fipronil desulfinyl

Fipronil sulfone

$\square$ Fipronil

$\square$ Fipronil sulfide

FIGURE 1. Intake contribution and residue distribution of fipronil. (A) Estimated daily intake contribution of total FIPs for different food categories from the Sixth China TDS; (B) Residue distribution of fipronil and its metabolites in different dietary categories.

Abbreviations: FIPs=fipronils; TDS=Total Diet Study. 
exposure of total FIPs in different PLADs from China was analyzed. Table 2 showed that the average EDI of total FIPs for the general population was $15.6 \mathrm{ng} / \mathrm{kg}$ body weight per day, accounting for $7.80 \%$ of the ADI (200 $\mathrm{ng} / \mathrm{kg}$ body weight per day) with a range from 0.39 to $136 \mathrm{ng} / \mathrm{kg}$ body weight per day for different PLADs in China. Figure 1A showed that eggs were the main dietary intake contributor of total FIPs for Chinese adult populations (55.3\%), followed by vegetables $(30.7 \%)$, meats $(5.90 \%)$, cereals $(5.30 \%)$, and other food categories contributed less than $2 \%$.

\section{DISCUSSION}

This study reported the contamination levels of total FIPs in 24 PLADs in the Sixth China TDS, and analyzed the distribution characteristics of fipronil and its metabolites. As shown in Figure 1B, fipronil was found to be a major residue in plant-derived samples, followed by fipronil sulfone. However, fipronil sulfone became the major residue in animal-derived samples, and the parent compound fipronil was less distributed. Besides, fipronil desulfinyl demonstrated another major distribution contribution in dairy and aquatic products. In total, for products of plant origins, fipronil and fipronil sulfone were the main characteristic contaminants, while for products of animal origins, fipronil sulfone and fipronil desulfinyl were found at higher quantifiable levels of residues due to inconsistent metabolic modes of the parent compound in the body and the photolysis mode in the environment.

Due to an outbreak of fipronil egg contamination in Europe, egg samples were one of the key concerns of this study. Among the 12 dietary categories, no matter from the detection frequency and detection concentration in this study, the egg samples were the worst. The maximum residue limit (MRL) of total FIPs in eggs was set at $20 \mu \mathrm{g} / \mathrm{kg}$ in China. In this study, the average concentration level of eggs in 24 PLADs was $21.4 \mu \mathrm{g} / \mathrm{kg}$, which exceeded the MRL in China. Details were shown in Supplementary Figure S2 (available in https://weekly.chinacdc.cn/). In addition, considering that the egg samples in this study belonged to composite dietary samples, it means that some individual egg samples were likely to exceed the current MRL value. Compared with the results of the Fifth China TDS (6), as shown in Supplementary Figure S3 (available in https://weekly.chinacdc.cn/), an upward trend for residue levels of total FIPs was observed in Sixth China TDS. Especially for egg samples, a significant increasing trend was observed for residue levels in Gansu, Inner Mongolia, and Liaoning PLADs from the Fifth to Sixth TDS, which exceeded the MRL with concentration levels of $383 \mu \mathrm{g} / \mathrm{kg}, 52.9$ $\mu \mathrm{g} / \mathrm{kg}$, and $42.8 \mu \mathrm{g} / \mathrm{kg}$, respectively.

The Sixth TDS results demonstrated that the EDIs of total FIPs in China were within acceptable levels with low health risk. However, the EDIs of total FIPs in Gansu accounted for $68.0 \%$ of the ADI, which was worthy of more attention. Compared with the results from the Fifth TDS (6), the EDI of total FIPs in Chinese adult populations increased slightly in the Sixth TDS. Among them, the contribution rate of animal-derived dietary intake to total EDI was greatly increased. The contribution of eggs was significant, which was mainly related to the high detection levels in Gansu, Inner Mongolia, and Liaoning. In the Fifth TDS, total FIPs were basically detected at $<1 \mu \mathrm{g} / \mathrm{kg}$, and the highest detectable concentration level was less than $9 \mu \mathrm{g} / \mathrm{kg}$, mainly from vegetables (6). However, in the Sixth TDS, the number of dietary samples for concentration level of $>1 \mu \mathrm{g} / \mathrm{kg}$ samples increased, and most of them appeared in animal-derived food. Therefore, to prevent improper or excessive use of fipronil, it is necessary to strengthen the monitoring and traceability for different kinds of animal-derived food, especially eggs.

This study was subject to some limitations. First, the current exposure assessment was based on the consumption patterns of Chinese adults, but it was not involved in that for infants and young children, which required follow-up breast milk monitoring or more detailed dietary exposure assessment at different ages. Second, the current exposure assessment only reflected the average exposure level of adults, but did not cover some highly exposed population with high consumption.

In conclusion, some suggestions are put forward to reduce the health risks of low-level fipronil exposure: 1) strengthen the monitoring of total FIPs in food, especially for animal-derived foods, such as eggs; and 2) seek the source of fipronil exposure in diet and provide some reliable suggestions for policymakers. Notably, fipronil, as the main active ingredient of hygienic insecticide, is still widely used in indoor hygiene and seed protection according to the Chinese pesticide information website (7). Several studies reported that fipronil exposure to indoor dust and environmental water reached noticeable levels $(8-10)$. Therefore, in addition to dietary exposure, other exposure pathways should be closely monitored. 
Conflicts of interest: No conflicts of interest reported.

Acknowledgements: The 24 provincial-level CDCs.

Funding: Supported by the National Key Research and Development Program of China (grant number 2017YFC1600500) and CAMS Innovation Fund for Medical Science (CIFMS 2019-I2M-5-024).

doi: $10.46234 / \mathrm{ccdcw} 2022.046$

\# Corresponding author: Dawei Chen, chendw@cfsa.net.cn.

${ }^{1}$ NHC Key Laboratory of Food Safety Risk Assessment, Chinese Academy of Medical Science Research Unit (No. 2019RU014), China National Center for Food Safety Risk Assessment, Beijing, China;

${ }^{2}$ Nanchang Key Laboratory of Detection and Control of Food Safety, Nanchang Inspection and Testing Center, Nanchang, Jiangxi Province, China.

Submitted: November 17, 2021; Accepted: February 26, 2022

\section{REFERENCES}

1. Gibbons D, Morrissey C, Mineau P. A review of the direct and indirect effects of neonicotinoids and fipronil on vertebrate wildlife. Environ Sci Pollut Res 2015;22(1):103 - 18. http://dx.doi.org/10.1007/s11356014-3180-5.

2. Goff AD, Saranjampour P, Ryan LM, Hladik ML, Covi JA, Armbrust $\mathrm{KL}$, et al. The effects of fipronil and the photodegradation product fipronil desulfinyl on growth and gene expression in juvenile blue crabs, Callinectes sapidus, at different salinities. Aquat Toxicol 2017;186:96 -
104. http://dx.doi.org/10.1016/j.aquatox.2017.02.027

3. Wu J, Lu J, Lu H, Lin YJ, Wilson PC. Occurrence and ecological risks from fipronil in aquatic environments located within residential landscapes. Sci Total Environ 2015;518-519:139 - 47. http://dx.doi. org/10.1016/j.scitotenv.2014.12.103.

4. Lyu B, Li JG, Wu YN. Characterizing the exposome of food contamination and China Total Diet Study: project for improving food safety risk assessment in China. China CDC Wkly 2022;4(9):157 - 60. http://dx.doi.org/10.46234/ccdcw2022.039.

5. Li SH, Chen DW, Lyu B, Li JG, Zhao YF, Wu YN. One-step coldinduced aqueous two-phase system for the simultaneous determination of fipronil and its metabolites in dietary samples by liquid chromatography-high resolution mass spectrometry and the application in Total Diet Study. Food Chem 2020;309:125748. http://dx.doi.org/ 10.1016/j.foodchem.2019.125748.

6. Chen DW, Li SH, Lyu B, Zhao YF, Li JG, Wu YN. The status and health risk assessment of dietary fipronil contamination among 20 provinces of China. Chin J Prev Med 2019;53(12):1242 - 6. http://dx. doi.org/10.3760/cma.j.issn.0253-9624.2019.12.008. (In Chinese).

7. China pesticide information network. 2021. http://www.chinapesticide. org.cn/hysj/index.jhtml.[2021-11-17].(in Chinese).

8. Shi LS, Chen L, Wan YJ, Zeng HC, Xia W. Spatial variation of fipronil and its derivatives in tap water and ground water from China and the fate of them during drinking water treatment in Wuhan, central China. Chemosphere 2020;251:126385. http://dx.doi.org/10.1016/j. chemosphere.2020.126385.

9. Shi LS, Jiang Y, Wan YJ, Huang J, Meng QQ, He ZY, et al. Occurrence of the insecticide fipronil and its degradates in indoor dust from South, Central, and North China. Sci Total Environ 2020;741:140110. http://dx.doi.org/10.1016/j.scitotenv.2020.140110.

10. Sadaria AM, Labban CW, Steele JC, Maurer MM, Halden RU. Retrospective nationwide occurrence of fipronil and its degradates in U.S. wastewater and sewage sludge from 2001-2016. Water Res 2019;155:465-73. http://dx.doi.org/10.1016/j.watres.2019.02.045. 


\section{Supplementary Data}

SUPPLEMENTARY TABLE S1. Mass spectrometric parameters of fipronil and its metabolites.

\begin{tabular}{|c|c|c|}
\hline Analytes & Parent ion $[\mathrm{M}-\mathrm{H}]^{-}(\mathrm{m} / \mathrm{z})$ & Fragment ions $(m / z)$ \\
\hline Fipronil & 434.931 & $329.960,249.958$ \\
\hline Fipronil desulfinyl & 386.969 & $350.987,281.992$ \\
\hline Fipronil sulfone & 450.926 & $414.950,281.992$ \\
\hline Fipronil sulfide & 418.936 & $382.960,313.964$ \\
\hline Fipronil- ${ }^{13} \mathrm{C}_{4}{ }^{15} \mathrm{~N}_{2}$ & 440.938 & l \\
\hline
\end{tabular}
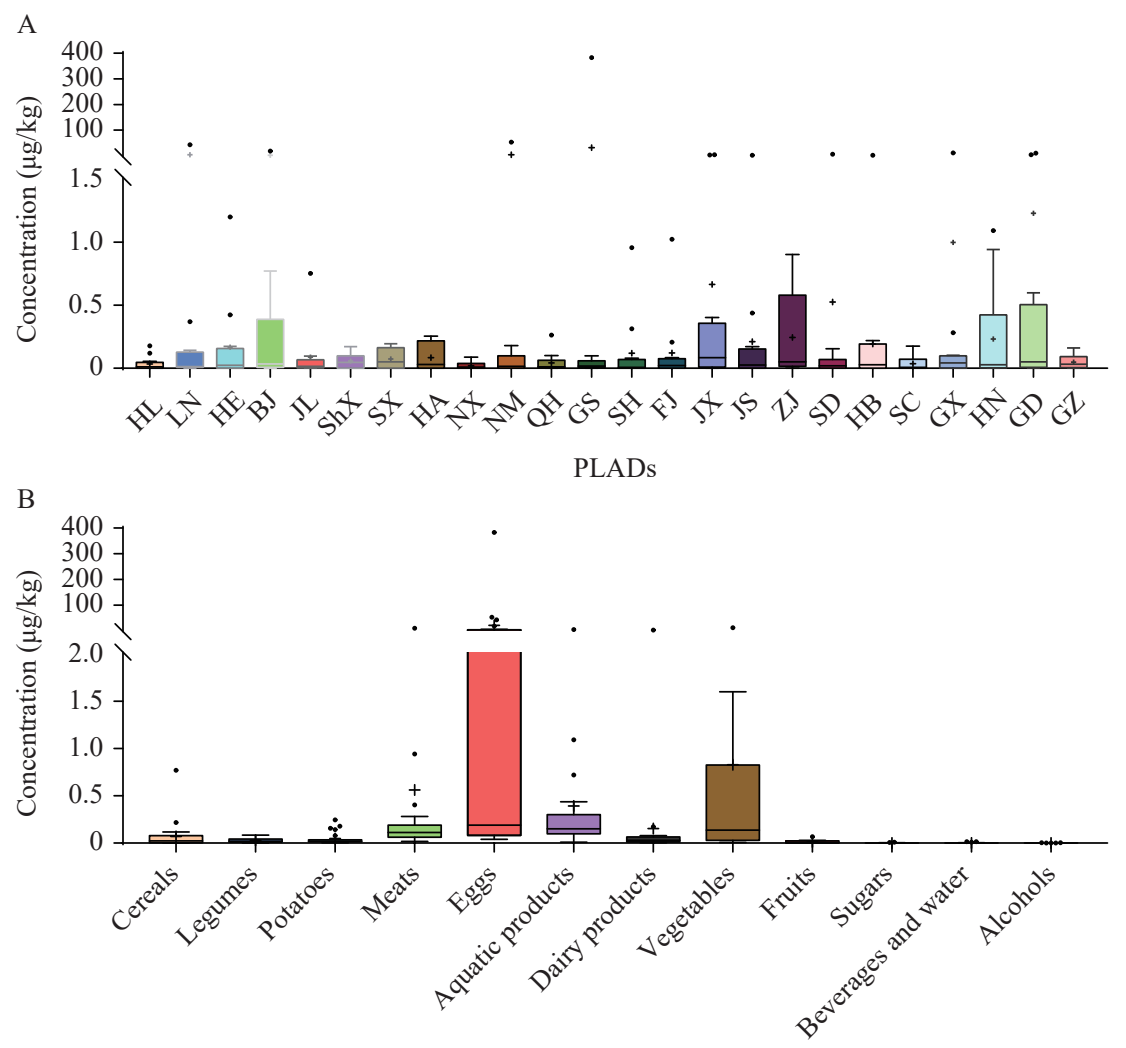

Dietary categories

SUPPLEMENTARY FIGURE S1. Total fipronils (FIPS) residue concentration. (A) Total FIPs residue concentration in 24 provincial-level administrative divisions from the Sixth China Total Diet Study (TDS); (B) Total FIPs residue concentration in different food categories from the Sixth China TDS, respectively. Concentrations are plotted on a box-and-whisker plot with 12 quartiles. Box limits were for the first and third quartiles, and the band inside the box was the second quartile (the median). Boxplot whiskers extended to 1.5 times the interquartile range. Outliers were represented by solid circles; "+" symbols indicate the mean value of residue data.

Abbreviations: TDS= total diet study; HLJ=Heilongjiang; LN=Liaoning; HE=Hebei; BJ=Beijing; JL=Jilin; SX=Shanxi; $\mathrm{SN}=$ Shaanxi; HA=Henan; NX=Ningxia; NM=Inner Mongolia; QH=Qinghai; GS=Gansu; SH=Shanghai; FJ=Fujian; JX=Jiangxi; JS=Jiangsu; ZJ=Zhejiang; SD=Shandong; HB=Hubei; SC=Sichuan; GX=Guangxi; HN=Hunan; GD=Guangdong; $\mathrm{GZ}=$ Guizhou. 


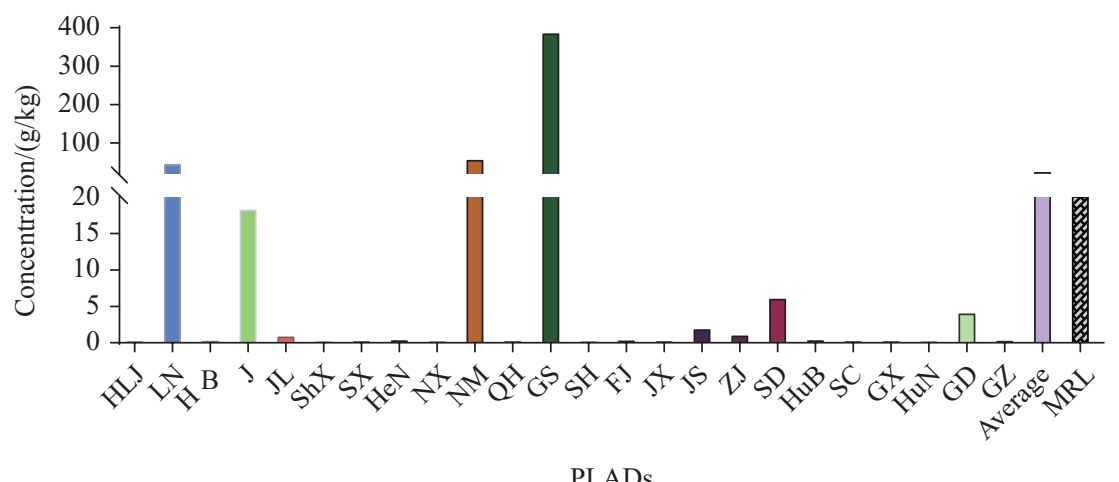

SUPPLEMENTARY FIGURE S2. Detection levels of total fipronils in egg samples from the 24 PLADs and the maximum residue limit value.

Abbreviations: HL=Heilongjiang; LN=Liaoning; HE=Hebei; BJ=Beijing; JL=Jilin; SX=Shanxi; SN=Shaanxi; HA=Henan; NX=Ningxia; NM=Inner Mongolia; QH=Qinghai; GS=Gansu; SH=Shanghai; FJ=Fujian; JX=Jiangxi; JS=Jiangsu; ZJ=Zhejiang; SD=Shandong; HB=Hubei; SC=Sichuan; GX=Guangxi; HN=Hunan; GD=Guangdong; GZ=Guizhou; $\mathrm{PLADs}=$ provincial-level administrative divisions. 


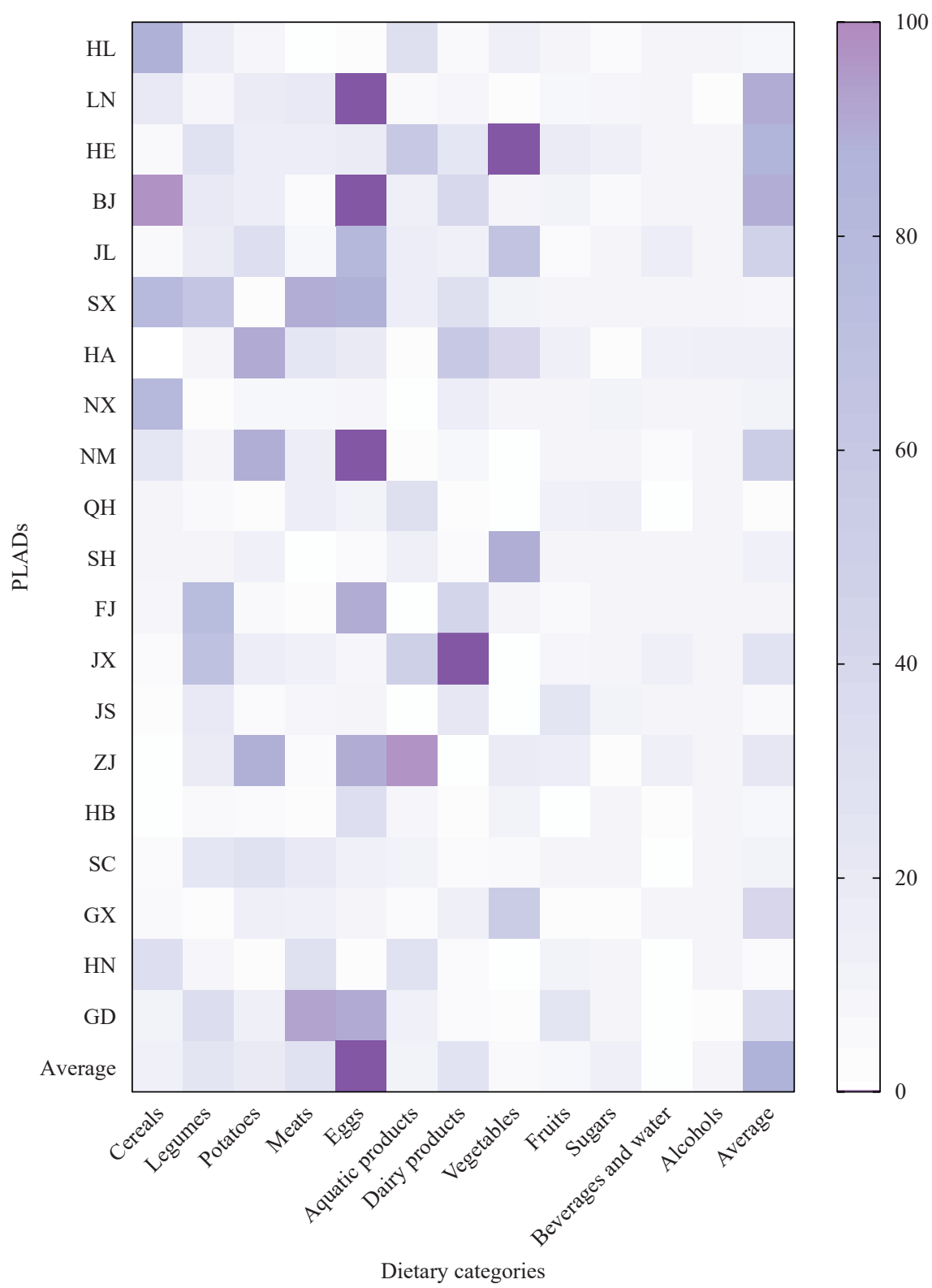

SUPPLEMENTARY FIGURE S3. Relative changes in ratio value of total fipronils (FIPs) concentration from 20 PLADs between the Fifth and Sixth China TDS.

Notes: The white and purple squares in the heatmap indicate decreased and increased residue levels of total FIPs, respectively.

Abbreviations: $H L=$ Heilongjiang; $L N=L i a o n i n g ; H E=H e b e i ; B J=B e i j i n g ; J L=J i l i n ; S X=S h a n x i ; H A=H e n a n ; N X=N i n g x i a ;$ $\mathrm{NM}=$ Inner Mongolia; $\mathrm{QH}=$ Qinghai; $\mathrm{SH}=$ Shanghai; $\mathrm{FJ}=$ Fujian; JX=Jiangxi; JS=Jiangsu; ZJ=Zhejiang; HB=Hubei; $\mathrm{SC}=$ Sichuan; $\mathrm{GX}=$ Guangxi; HN=Hunan; GD=Guangdong; PLADs=provincial-level administrative divisions; TDS=Total Diet Study. 